\title{
Analysis of lipophilic compounds in needles of Pinus pinea $\mathrm{L}$.
}

\author{
Brígida Fernández de Simón a, ${ }^{\text {, }}$ María Concepción García Vallejo a , Estrella Cadahía ${ }^{a}$, \\ Carlos Arrabal Miguel ${ }^{\mathrm{b}}$ and Manuel Cortijo Martinez ${ }^{\mathrm{b}}$ \\ a Departamento de Industrias Forestales, INIA-CIFOR, Apdo. 8111, 28080 Madrid, Spain \\ b Departamento de Ingeniería Forestal, ETSI Montes, Universidad Politécnica de Madrid, Ciudad Universitaria, \\ 28040 Madrid, Spain.
}

(Received 17 February 2000; accepted 22 September 2000)

\begin{abstract}
Monoterpene, sesquiterpene, neutral diterpene, fatty and resin acids were analyzed in needles of Pinus pinea. Together these compounds represent a mean of $6 \mathrm{mg} \mathrm{g}^{-1}$ of fresh needles. Sixty-five different compounds were identified. The main components were: $l$-limonene (monoterpene), $\beta$-caryophyllene and germacrene D (sesquiterpenes), (11E,13Z)-labdadien-8-ol and abienol (neutral diterpenes), oleic and stearic acids (fatty acids) and abietic, isopimaric, levopimaric, palustric, and dehydroabietic acids (resin acids). Fifty-six compounds were described for the first time in needles of this Pinus species.
\end{abstract}

Pinus pinea / needle / terpenes / fatty acids / resin acids

Résumé - Analyse des composés lipophiles dans les aiguilles de Pinus pinea L. Monoterpenes, sesquiterpenes, diterpenes neutres, et acides gras et résiniques ont été analysés dans les aiguilles de Pinus pinea. Ces composés représentent ensemble une moyenne de $6 \mathrm{mg} \mathrm{g}^{-1}$ d'aiguille fraîche. Soixante cinq composés différents ont été identifiés. Les composés les plus importants ont été : $l$-limonene (monoterpenes), $\beta$-cariofilene et germacrene D (sesquiterpenes), (11E,13Z)-labdadien-8-ol et abienol (diterpenes neutres), acides oléique et stéarique (acides gras) et acides abiétique, isopimarique, levopimarique, palustrique et dehydroabietique (acides résiniques). Cinquante six composés ont été décrits pour la première fois dans les aiguilles de cette espèce de pin.

Pinus pinea / aiguille / terpenes / acides gras / acides résiniques

\section{INTRODUCTION}

In the last few years, because of the application of reforestation politics, a new tendency towards Pinus pinea expansion has appeared. Research is being carried out to find selected individuals with a good oleoresin production, which consisting mainly of limonene and abietic and levopimaric acids [7, 12], to be used as seed producers [3]. The tapping of $P$. pinea resin often requires the application of suitable methods because of its high crystallization speed. The monoterpenes of Pinus spp. are dependent upon the plant genotype and can be used as biochemical markers in many genetic experiments and ecological studies $[2,4,6,11]$. The study of these compounds is mainly carried out in needles because the

* Correspondence and reprints

Tél. (34) 91347 6783; Fax. (34) 91357 2293; e-mail: fdesimon@inia.es 
epithelium of their resin canals is the basic tissue responsible for the production of terpenes; however cortical monoterpenes are considered more stable [2] because foliar monoterpenes are related to the age of the needle. The main monoterpenes in $P$. pinea needles are limonene (until 87\%), $\alpha$-pinene (10\%) and $\beta$-pinene and myrcene $(2 \%)[10,12]$. Roussis et al. [10] identified 37 neutral components, and among them, besides those already cited, $\beta$-phelandrene, caryophyllene, germacrene $\mathrm{D}$, guaiol and the diterpenes $(5,9 \alpha, 10 \beta)$-kaur-15-ene and (11E,13Z)-labdadien-8-ol, stand out. The sequence limonene $>$ germacrene $\mathrm{D}>\alpha$-pinene $>\beta$-pinene, characterizes the chemotype found by them. Although there are many papers in the literature on the resin acids composition of needles of many Pinus spp, to our knowledge, no study has been carried out on fatty and/or resin acids in $P$. pinea needles. Because of their chemical stability and presumed physiological stability, resin acids are also considered to be valuable tools in pine taxonomy and genetic investigations $[14,15,17,18]$. In the last few years, new methods have been described for a simultaneous analysis of monoterpenes, sesquiterpenes and diterpenes (neutral and acids) in conifer oleoresin [8, 13]. The method we chose consists of a simultaneous extraction of neutral and acid compounds from the needles and the further analysis of the extracts by GC-MS. In this paper, we study the lipophilic components in Pinus pinea needles, of the same age (two years old) in order to avoid the age factor in the needle composition.

\section{MATERIALS AND METHODS}

Samples. The selected study areas were two plots of natural forest in Valladolid province, in Central Spain: Montellano de San Marugán (Portillo) and Monte Santinos (Tudela de Duero). Two-year-old needles were sampled, in April 1999, from nine trees more than 100 years old. The needles were immediately frozen at $-70{ }^{\circ} \mathrm{C}$, in liquid nitrogen, and stored likewise until they were analyzed.

Extraction. The needles were cut into small pieces (2-4 mm). A known weight ( $3 \mathrm{~g}$, approx.) was extracted for $24 \mathrm{~h}$ at $4{ }^{\circ} \mathrm{C}$ with $5 \mathrm{~mL}$ of petroleum ether/diethyl ether (1:1). Isobuthylbencene $\left(125 \mu \mathrm{g} \mathrm{mL}^{-1}\right)$, heptadecane $\left(68 \mu \mathrm{g} \mathrm{mL}^{-1}\right)$ and heptadecanoic acid $\left(150 \mu \mathrm{g} \mathrm{mL}^{-1}\right)$ were used as internal standards. The extract was then decanted and the volatile terpenes in this extract were analyzed by gas chromatography (GC). The solvent was removed from the remaining extract together with $2 \mathrm{~mL}$ from the needle washing, in a nitrogen stream. The dried extract was redissolved in $1 \mathrm{~mL}$ of methanol and analyzed (fatty and resin acids) by GC, after adding $100 \mu \mathrm{L}$ of methylation reagent (tetramethylammonium hydroxide).

Chromatographic analysis. The extracted compounds were separated and identified by gas chromatography/mass spectrometry (GC-MS) using a HP 5890A gas chromatograph connected to a HP 5971A mass detector (EI, $70 \mathrm{eV}$ ) and equipped with a $30 \mathrm{~m} \times 0.25 \mathrm{~mm}$ i. d., PTE-5 capillary column $(0.25 \mu \mathrm{m}$ film thickness $)$. The working conditions were: injector temperature, $260{ }^{\circ} \mathrm{C}$; detector temperature, $300{ }^{\circ} \mathrm{C}$; column temperature, $60{ }^{\circ} \mathrm{C}$ during the split period $(2 \mathrm{~min})$, and then heated, at $4{ }^{\circ} \mathrm{C} \mathrm{min}{ }^{-1}$, to $270{ }^{\circ} \mathrm{C}(10 \mathrm{~min})$. Helium flow was adjusted to $0.5 \mathrm{~mL} \mathrm{~min}{ }^{-1}$. For quantitative measurements, by the internal standard method, additional injections of replicate samples were made using a flame ionization detector, under the same working conditions. The identification of the compounds was assessed by their retention times and their EI mass spectra, by comparing them with those in the database (Wiley Mass Spectral Database, 1986; Nist/Epa/Nih Mass Spectral Database, 1995) and in the literature. The methyl ester of epiimbricataloic acid was identified by comparing its retention time and mass spectrum with those of an authentic sample, provided by Dr. Duane F. Zinkel.

\section{RESULTS AND DISCUSSION}

In $P$. pinea needles the overall mean of the studied compounds was $6 \mathrm{mg} \mathrm{g}^{-1}$ of fresh needles, although the range of concentrations was between 1.91 and $13.91 \mathrm{mg} \mathrm{g}^{-1}$ of needles (table I). More than half were diterpenes: resin acids (48-62\%) and neutral diterpenes (11-19\%). Monoterpenes (12-15\%), sesquiterpenes (3-4\%) and fatty acids, with the highest differences between trees, from 5 to $21 \%$, make up the rest. However, considering the concentrations as $\mathrm{mg} \mathrm{g}^{-1}$ of needles, these variations were lower, because they are not affected by the fluctuations in the concentrations of the other compounds. In this case, resin acids show the highest concentration variations between trees, from 0.94 to $8.71 \mathrm{mg} \mathrm{g}^{-1}$ of needles.

In table II, the composition of neutral fraction can be seen. Ten monoterpenes were identified: 8 hydrocarbons, 1 alcohol and 1 ether. Their percentages agreed with data in the literature $[10,12]$. Thus, the highest percentage was $l$-limonene, with few differences between trees, since their values only vary between 
Table I. Presence of monoterpene, sesquiterpene, neutral diterpene, fatty acids and resin acids in needles of Pinus pinea.

\begin{tabular}{|c|c|c|c|c|c|c|c|c|c|c|c|}
\hline Tree & 1 & 2 & 3 & 4 & 5 & 6 & 7 & 8 & 9 & $x$ & $\mathrm{sd}$ \\
\hline \multicolumn{12}{|l|}{$\mathrm{mg} \mathrm{g}^{-1}$ needle } \\
\hline Monoterpene & 0.81 & 0.37 & 0.78 & 0.26 & 0.57 & 0.91 & 0.85 & 1.94 & 0.93 & 0.82 & 0.48 \\
\hline Sesquiterpene & 0.22 & 0.11 & 0.22 & 0.07 & 0.17 & 0.19 & 0.26 & 0.56 & 0.26 & 0.23 & 0.14 \\
\hline Neutral Diterpene & 0.77 & 0.39 & 1.10 & 0.22 & 0.54 & 1.06 & 1.09 & 2.01 & 0.98 & 0.91 & 0.52 \\
\hline Fatty Acids & 0.97 & 0.53 & 0.51 & 0.41 & 0.63 & 0.67 & 0.56 & 0.69 & 0.56 & 0.61 & 0.16 \\
\hline Resin Acids & 3.56 & 1.34 & 3.17 & 0.94 & 2.09 & 3.16 & 3.37 & 8.71 & 3.38 & 3.30 & 2.24 \\
\hline $\mathrm{mg}$ total & 6.33 & 2.75 & 5.77 & 1.91 & 4.00 & 5.99 & 6.12 & 13.91 & 6.11 & 5.88 & 3.43 \\
\hline \multicolumn{12}{|l|}{$\%$ total extract } \\
\hline Monoterpene & 12.75 & 13.61 & 13.47 & 13.73 & 14.34 & 15.18 & 13.83 & 13.94 & 15.26 & 14.01 & 0.81 \\
\hline Sesquiterpene & 3.55 & 4.07 & 3.74 & 3.88 & 4.23 & 3.20 & 4.25 & 4.05 & 4.30 & 3.92 & 0.37 \\
\hline Neutral Diterpene & 12.09 & 14.34 & 19.05 & 11.47 & 13.51 & 17.69 & 17.73 & 14.44 & 15.99 & 15.15 & 2.64 \\
\hline Fatty Acids & 15.35 & 19.30 & 8.82 & 21.62 & 15.64 & 11.17 & 9.17 & 4.98 & 9.10 & 12.79 & 5.49 \\
\hline Resin Acids & 56.26 & 48.69 & 54.92 & 49.30 & 52.28 & 52.76 & 55.02 & 62.59 & 55.35 & 54.13 & 4.14 \\
\hline
\end{tabular}

$x=$ average; $s d=$ standard deviation.

75-84\%. $\alpha$-Pinene (10\%), $\beta$-pinene and myrcene $(3 \%)$ were other characteristic constituents of the monoterpene fraction. We found 26 sesquiterpenes, of which 23 were identified: 11 hydrocarbons, 7 alcohols and 5 ethers (table II). $\beta$-Caryophyllene and germacrene $\mathrm{D}$ were the highest sesquiterpene percentages, as described already for needles of $P$. pinea and other Pinus spp. [9, 10]. However, the chemotype described for the essential oil from $P$. pinea needles (limonene $>$ germacrene $\mathrm{D}>\alpha$-pinene $>$ $\beta$-pinene) [10] does not match with our results, except for the relative concentrations of monoterpenes: limonene > $\alpha$-pinene $>\beta$-pinene. In our samples the germacrene D concentrations were always lower than those of $\beta$ pinene, and also lower than those of $\beta$-caryophyllene. Other constituents of the sesquiterpene fraction reached percentages higher than 5\%: guaiol and three farnesol derivatives: acetate, isovaleranate and others not fully identified. Guaiol, $(E, E)$-farnesol acetate and $\alpha$-humulene have been described in $P$. pinea needles [10] previously. All the sesquiterpenes identified by us have been reported in other Pinus spp. [9].

Nineteen neutral diterpenes were identified: 4 hydrocarbons, 3 alcohols, 4 aldehydes and 8 methyl esters of resin acids (table II). The most important components were the alcohols, particularly the bicyclic diterpene alcohol (11E,13Z)-labdadien-8-ol, a precursor in the biosynthesis of tetracyclic plant hormones (gibberellins), which reached concentrations up to $45 \%$ of total neutral diterpenes. Roussis et al. (1995) [10] found this compound in the essential oil of $P$. pinea, but in lower concentrations. Conversely, they found significant amounts of the next compound in the biosynthesis process of these hormones - $(5,9 \alpha-10 \beta)$-kaur-15-ene-, probably because the needles were collected in a different stage of development. The other alcohols identified were the labdane type, abienol (10\%) and the isopimarane type, isopimarol (1.5\%). The latter was found in P. pinea oleoresin in significant percentages [7], and in $P$. pinea wood, but in minor percentages [5]. In oleoresin, in addition to isopimarol, Lange and Weißmann (1991) [7] found other two diterpenic alcohols, pointing out that $43 \%$ of the hydroxylated fraction were alcohols of the labdane type, the same as that found by us in needles. The methyl esters of resin acids were the second most important fraction of neutral diterpenes. They are naturally present in needles since they were found in the extract before methylation. Their overall concentration ranged between 28 and 44\% of total neutral diterpenes. The couple methyl levopimarate + methyl palustrate were the most abundant components, followed by methyl dehydroabietate and methyl abietate. The identification of the methyl 19-nor-12-oxo-3,5,8-abietatrienate, found by Lange and Weißmann (1991) [7] in oleoresin from P. sylvestris and $P$. pinea, was made by comparison of its mass spectra with those published by these authors. Other diterpenes 
Table II. Monoterpene, sesquiterpene and neutral diterpene in needles of Pinus pinea (\% in each fraction).

\begin{tabular}{|c|c|c|c|c|c|}
\hline \multicolumn{3}{|l|}{ Peak } & \multicolumn{3}{|l|}{ Peak } \\
\hline Monoterpenes & $x$ & sd & Sesquiterpenes & $x$ & sd \\
\hline a-Pinene & 10.31 & 2.82 & Longifolene & 1.53 & 0.66 \\
\hline Sabinene & 0.59 & 0.16 & $\beta$-Caryophyllene & 13.93 & 3.16 \\
\hline$\beta$-Pinene & 3.38 & 0.87 & $\delta$-Guaiene & 0.56 & 0.06 \\
\hline Myrcene & 3.18 & 0.18 & 3,7-Guaiadiene & 3.36 & 0.41 \\
\hline$\alpha$-Phellandrene & 0.37 & 0.15 & $\alpha$-Guanene & 1.48 & 0.13 \\
\hline$l$-Limonene & 79.04 & 3.54 & $\alpha$-Humulene & 2.98 & 0.76 \\
\hline trans-Ocimene & 1.11 & 0.69 & $\gamma$-Muurolene & 0.84 & 0.09 \\
\hline$\alpha$-Terpinolene & 0.53 & 0.11 & Germacrene D & 10.09 & 2.52 \\
\hline 1- $\alpha$-Terpineol & 0.35 & 0.14 & Farnesene & 0.96 & 0.77 \\
\hline Methyl-thymyl ether & 1.12 & 0.57 & Isolongifolene & 3.51 & 0.38 \\
\hline Diterpenes & $x$ & sd & 2,6-Ditertbuthyl $p$-cresol & 0.60 & 0.10 \\
\hline Neophytadiene & 1.12 & 0.80 & 2,6-Ditertbuthyl phenol & 3.22 & 1.98 \\
\hline 19-Nor-4,8,11,13-abietatetraene & 1.18 & 0.18 & $\delta$-Cadinene & 0.72 & 0.25 \\
\hline 19-Nor-6,8,11,13-abietatetraene & 3.11 & 2.65 & Globulol & 1.73 & 0.39 \\
\hline 8,13-Abietadiene & 0.46 & 0.15 & Guaiol & 9.60 & 1.52 \\
\hline (11E,13Z)-Labdadien-8-ol & 39.11 & 5.38 & T-Cadinol & 3.78 & 0.69 \\
\hline Abienol & 10.18 & 1.74 & Sesquiterpene oxygenated & 0.86 & 0.38 \\
\hline Isopimaral & 4.13 & 2.06 & $\beta$-Eudesmol & 0.93 & 0.23 \\
\hline Levopimaral & 3.78 & 0.62 & Sesquiterpene & 3.05 & 0.66 \\
\hline Dehydroabietal & 0.71 & 0.19 & (E.E)-Farnesol & 0.57 & 0.29 \\
\hline Methyl isopimarate & 1.71 & 0.33 & (E.E)-Farnesol, acetate & 11.87 & 5.12 \\
\hline Methyl levopimarate + methyl palustrate & 15.90 & 2.97 & Sesquiterpene oxigenated & 2.21 & 1.12 \\
\hline Isopimarol & 1.49 & 0.84 & Farnesol derivative & 9.76 & 2.33 \\
\hline Methyl dehydroabietate & 4.93 & 1.31 & (Z.E)-Farnesol, propionate & 0.98 & 0.14 \\
\hline Neoabietal & 2.48 & 1.56 & (E.E)-Farnesol, propionate & 3.38 & 0.81 \\
\hline Methyl abietate & 4.04 & 0.94 & (E.E)-Farnesol, isovaleranate & 7.49 & 1.91 \\
\hline Methyl podocarpate & 0.51 & 0.34 & & & \\
\hline Methyl neoabietate & 2.99 & 0.45 & & & \\
\hline Methyl 19-nor-12-oxo-3,5,8-abietatrienate & 2.16 & 0.52 & & & \\
\hline
\end{tabular}

$x=$ average $; \mathrm{sd}=$ standard deviation.

identified, as the aldehydes isopimaral, levopimaral, dehydroabietal and neoabietal, were also found in the oleoresin from $P$. pinea [7]. However, the hydrocarbons showed the lowest percentages of neutral diterpenes, the converse of the situation in monoterpene and sesquiterpene fractions. Among the hydrocarbons identi- fied, neophytadiene has been reported in $P$. pinea plant material; and 19-nor-4,8,11,13-abietatetraene, in soil of a $P$. pinea forest [1].

Table III shows the composition of the fractions of fatty and resin acids, analyzed as methyl esters. The main 
Table III. Fatty and resin acids, such as methyl esters, in needles of Pinus pinea (\% methylated fatty and resin acid fractions, respectively).

\begin{tabular}{lcclll}
\hline Peak & & & Peak & & \\
\hline Fatty acids & $\boldsymbol{x}$ & sd & Resin acids & $\boldsymbol{x}$ & sd \\
Lauric $\mathrm{C}_{12: 0}$ & 2.08 & 0.518 & Seco $1^{*}$ & 0.24 & 0.109 \\
Miristic $\mathrm{C}_{14: 0}$ & 3.54 & 0.809 & Seco 2** & 0.71 & 0.158 \\
Unidentified & 1.25 & 0.296 & Pimaric & 1.63 & 0.677 \\
Palmitic $\mathrm{C}_{16: 0}$ & 15.05 & 1.991 & Sandaracopimaric & 2.12 & 0.239 \\
Unidentified & 2.91 & 0.534 & Isopimaric & 17.22 & 2.003 \\
Oleic $\mathrm{C}_{18: 1}$ & 30.26 & 4.82 & Levopimaric + Palustric & 15.28 & 8.83 \\
Estearic $\mathrm{C}_{18: 0}$ & 22.62 & 5.154 & Dehydroabietic & 15.57 & 2.487 \\
13-hydroxy-9-octadecenoic & 5.92 & 2.204 & Unidentified & 0.52 & 0.108 \\
Octadecanodioic & 7.43 & 0.705 & Abietic & 29.95 & 4.118 \\
Eicosanoic $\mathrm{C}_{20: 0}$ & 4.39 & 2.388 & Podocarpic & 0.48 & 0.328 \\
Behenic $\mathrm{C}_{22: 0}$ & 3.23 & 0.825 & Epiimbricataloic & 2.31 & 0.568 \\
Lignoceric $\mathrm{C}_{24: 0}$ & 1.32 & 1.244 & Neoabietic & 5.18 & 1.889 \\
& & & Unidentified & 0.55 & 0.179 \\
& & & Oxohydroxydehydroabietic isomer & 0.69 & 0.161 \\
& & & Oxohydroxydehydroabietic isomer & 3.55 & 1.883 \\
& & & 19-Nor-12-oxo-3,5,8-abietatrienoic & 0.72 & 0.207 \\
& & & Unidentified & 0.75 & 0.437 \\
\hline
\end{tabular}

$x=$ average; $\mathrm{sd}=$ standard deviation; $*$ Seco $1=2 \alpha-\left[2^{\prime}\left(m\right.\right.$-isopropyl-phenyl)ethyl]-1 $\beta .3 \alpha$-dimethyl-cyclo-hexanecarboxylic; $* *$ Seco $2=2 \beta-\left[2{ }^{\prime}(m-\right.$ isopropylphenyl)ethyl]-1 $\beta .3 \alpha$-dimethyl-cyclohexanecarboxylic.

fatty acids were oleic, stearic and palmitic acids, and together reached $70 \%$ of total fatty acids. Their percentages show significant variations between trees, particularly those of oleic and stearic acids. Thus, they vary from 18 to $34 \%$ for stearic acid, and 21 to $37 \%$ for oleic acid. Similar variations are shown by other minor fatty acids.

The resin acids were the main fraction in the extract analyzed. Together they represented more than $50 \%$ of total extract and around $80 \%$ of diterpenes. High percentages of abietic acid (25-37\%) were observed. This acid was also the main resin acid in wood [4] and oleoresin [5] of $P$. pinea. Moreover, seco 1, seco 2, pimaric, sandaracopimaric, isopimaric, the couple of levopimaric
+ palustric, dehydroabietic, and neoabietic acids were found by Lange and Weißmann (1991) [7] in oleoresin of $P$. pinea; the last seven acids in wood and bark by Hafizoglu (1989) [5], and the first six, in soil of a $P$. pinea forest and in plant material from this Pinus species [1]. All of them have been described in needles of several Pinus species. Other minor resin acids found by us were: epiimbricataloic $[15,16,18]$, podocarpic and 19-nor-12oxo-3,5,8-abietatrienoic acids. The variation of resin acid concentrations between trees was not very great, except for the couple levopimaric + palustric, whose percentages, with respect to total resin acids varied between 4 and $28 \%$. The levels of these acids in trees 7 and 8 were very similar to those of abietic acid, the main resin acid. 


\section{CONCLUSIONS}

The chemical composition of Pinus pinea needles with respect to the fractions of monoterpenes, sesquiterpenes, diterpenes and fatty acids was very complex, as in other Pinus spp. Among the neutral compounds, the most abundant was $l$-limonene, and high concentrations of $(11 E, 13 Z)$-labdadien-8-ol, precursor in gibberellins biosynthesis were observed. On the other hand, the diterpenes constituted more than $60 \%$ of the extract analyzed, and of these, the resin acids were the most abundant fraction. Abietic acid was the main resin acid. For the majority of components analyzed, small differences between trees were found. However, some compounds, such as the couple levopimaric acid + palustric acid, showed large variations in concentration, which can affect the extract yields.

The method used makes an easy and rapid analysis of lipophilic compounds of needles possible, which can be used to the study of a large number of samples in the shortest possible time. These studies will clarify whether a possible correlation between lipophilic composition of needles and seed characteristics can be established.

\section{REFERENCES}

[1] Almendros G., Sanz J., Velasco F., Signatures of lipid assemblages in soils under continental Mediterranean forests, Eur. J. Soil Sci. 47 (1996) 183-196.

[2] Baradat Ph., Marpeau, A., Walter, J., Terpene markers, in: Muller Starck G., Ziehe M. (Eds.), Genetic variation in European populations of forest trees, Sauerlander's Verlag, Frankfurt am Main, 1991, pp. 40-66.

[3] Carvalho J.S., Caracterizaçao Química do Pinhao de $P i$ nus pinea L., Silva Lusitana 4 (1996) 1996

[4] Cates R.G., The role of mixture and variation in the production of terpenoids in conifer-insect pathogen interactions, in: Romeo J.T., Saunders J.A., Barbosa P. (Eds.), Phytochemical di- versity and redundancy in ecologycal interactions, Vol. 30, Plenum Press, New York, 1996, pp. 179-216.

[5] Hafizoglu H., Studies on the wood and bark constituents of Pinus pinea L., Holzforschung 43 (1989) 41-43.

[6] Hanover J.W., Applications of terpene analysis in forest genetics, New Forest 6 (1992) 159-178.

[7] Lange W., Weißmann G., Studies on the gum oleoresins of Pinus resinosa Ait and Pinus pinea L., Holz als Roh- und Werkstoff 49 (1991) 476-480.

[8] Lewinsohn E., Savage T.J., Gijzen M., Croteau R., Simultaneous analysis of monoterpenes and diterpenoids of conifer oleoresin, Phytochem. Anal. 4 (1993) 220-225.

[9] Pauly G., Gleizes M., Bernard-Dagan C., Identification des constituants de l'essence des aiguilles de Pinus pinaster, Phytochemistry 12 (1973) 1395-1398.

[10] Roussis V., Petrakis P.V., Ortiz A., Mazomenos B.E., Volatile constituents of needles of five Pinus species grown in Greece, Phytochemistry 39 (1995) 357-361.

[11] Rudolf von E., Volatile leaf analysis in chemosystematic studies of North American conifers, Biochem. Sist. Ecol. 2 (1969) 131-167.

[12] Silva M.M.N.P., O pinheiro manso (Pinus pinea): as potentialidades químicas dos seus produtos, in: I Simposio de aprovechamiento de resinas naturales, Actas científicas. Segovia, 1998, pp. 87-92.

[13] Song Z.Q., Chen C.L., Perry J.P., Characterization of mono-, sesqui- and di-terpenes in some Mexican and Guatemalan pine oleoresin. A simple GC method, Chem. Indust. For. Prod. 2 (1988) 10-18.

[14] Squillace A.E., Hedrick G.W., Green A.J., Variation and inheritance of levopimaric acid content and its relationship to oleoresin yield in Slash pine, Silvae Genetica 20 (1971) 90-91.

[15] Tobolski J.J., Zinkel D.F., Variation in needle and cortex resin acids during shoot development in Pinus sylvestris, $P$. nigra and P. strobus, For. Sci. 28 (1982) 785-796.

[16] Zinkel D.F., Diterpene resin acids of Pinus densiflora needles and cortex, Phytochemistry 15 (1976) 1073-1074.

[17] Zinkel D.F., Pine resin acids as chemotaxonomic and genetic indicators, in: TAPPI Conf. Papers, For. Biol. Wood Chem. Conf., Madison, 1977, pp. 53-56.

[18] Zinkel D.F., Magee T.V., Walter J. Major resin acids of Pinus nigra needles, Phytochemistry 24 (1985) 1273-1277. 